\title{
Role of Lidar Technology in Future NASA Space Missions
}

\section{FARZIN AMZAJERDIAN}

NASA Langley Research Center, MS 468, Hampton, VA 23681

(757) 864-1533, f.amzajerdian@nasa.gov 


\section{ABSTRACT}

The past success of lidar instruments in space combined with potentials of laser remote sensing techniques in improving measurements traditionally performed by other instrument technologies and in enabling new measurements have expanded the role of lidar technology in future NASA missions. Compared with passive optical and active radar/microwave instruments, lidar systems produce substantially more accurate and precise data without reliance on natural light sources and with much greater spatial resolution. NASA pursues lidar technology not only as science instruments, providing atmospherics and surface topography data of Earth and other solar system bodies, but also as viable guidance and navigation sensors for space vehicles. This paper summarizes the current NASA lidar missions and describes the lidar systems being considered for deployment in space in the near future.

\section{CURRENT SPACE-BASED LIDARS}

Presently, NASA has four major lidar instruments in space with another to be launched later this year. The ICESat (Ice, Cloud and land Elevation Satellite) and CALIPSO (CloudAerosol Lidar and Infrared Pathfinder Satellite Observation) are Earth science missions providing valuable atmospheric data and monitoring global climate changes [1-4]. The other three instruments are part of planetary missions: Mercury Laser Altimeter (MLA) as part of the MESSENGER (MErcury Surface, Space ENvironment, GEochemistry, and Ranging) mission [5], Mars Meteorological Lidar onboard Phoenix Lander and Lunar Orbiter Laser Altimeter (LOLA) onboard the Lunar Reconnaissance Orbiter. Table 1 summarizes the high-level specifications of these instruments and their launch dates. All these instruments utilize diodepumped Nd:YAG laser as their transmitter source and incorporate some level of redundancy by using backup lasers to ensure long operational lifetime in space.

Table 1 Current NASA Space-based Scientific Lidar Instruments

\begin{tabular}{|c|c|c|c|c|c|c|c|c|c|c|}
\hline Mission & $\begin{array}{c}\text { Lidar } \\
\text { instruments }\end{array}$ & $\begin{array}{c}\text { Primary data } \\
\text { products }\end{array}$ & $\begin{array}{c}\text { Pulse } \\
\text { energy }\end{array}$ & $\begin{array}{c}\text { Rep } \\
\text { rate }\end{array}$ & $\begin{array}{c}\text { No. of } \\
\text { bars }\end{array}$ & $\begin{array}{c}\text { Peak } \\
\text { power/bar }\end{array}$ & $\begin{array}{c}\text { No. } \\
\text { of } \\
\text { lasers }\end{array}$ & $\begin{array}{c}\text { Telescope } \\
\text { aperture } \\
\text { diameter }\end{array}$ & $\begin{array}{c}\text { Launch } \\
\text { date }\end{array}$ & $\begin{array}{c}\text { Required } \\
\text { lifetime } \\
\text { in space }\end{array}$ \\
\hline $\begin{array}{c}\text { ICESat } \\
\text { (Earth Science) }\end{array}$ & $\begin{array}{c}\text { Laser } \\
\text { altimeter with } \\
\text { atm channel }\end{array}$ & $\begin{array}{c}\text { Ice sheet } \\
\text { height, clouds }\end{array}$ & $110 \mathrm{~mJ}$ & 40 & 54 & $65-85 \mathrm{~W}$ & 3 & $100 \mathrm{~cm}$ & $\begin{array}{l}\text { January } \\
12,2003\end{array}$ & 3 \\
\hline $\begin{array}{c}\text { CALIPSO } \\
\text { (Earth Science) }\end{array}$ & $\begin{array}{c}\text { Atmospheric } \\
\text { backscatter }\end{array}$ & $\begin{array}{c}\text { Clouds and } \\
\text { aerosol } \\
\text { profiles }\end{array}$ & $220 \mathrm{~mJ}$ & 20 & 192 & $50 \mathrm{~W}$ & 2 & $100 \mathrm{~cm}$ & $\begin{array}{c}\text { April 28, } \\
2006\end{array}$ & 3 \\
\hline MESSENGER & $\begin{array}{c}\text { Laser } \\
\text { altimeter }\end{array}$ & $\begin{array}{c}\text { Mercury } \\
\text { surface } \\
\text { topography }\end{array}$ & $20 \mathrm{~mJ}$ & 8 & 10 & $100 \mathrm{~W}$ & 1 & $\begin{array}{c}11.5 \mathrm{~cm} \\
\times 4\end{array}$ & $\begin{array}{c}\text { August } 3, \\
2004\end{array}$ & 7 \\
\hline $\begin{array}{c}\text { Phoenix Mars } \\
\text { Lander }\end{array}$ & $\begin{array}{c}\text { Atmospheric } \\
\text { backscatter }\end{array}$ & $\begin{array}{c}\text { Mars aerosol, } \\
\text { ice clouds }\end{array}$ & & & & & & & $\begin{array}{c}\text { August } 4, \\
2007\end{array}$ & \\
\hline $\begin{array}{c}\text { Lunar } \\
\text { Reconnaissance } \\
\text { Orbiter }\end{array}$ & $\begin{array}{c}\text { Laser } \\
\text { altimeter }\end{array}$ & $\begin{array}{c}\text { Global lunar } \\
\text { topographic } \\
\text { model }\end{array}$ & $2.7 \mathrm{~mJ}$ & 28 & 4 & $70 \mathrm{~W}$ & 2 & $14 \mathrm{~cm}$ & Late 2008 & 2 \\
\hline
\end{tabular}


ICESat, CALIPSO and the Phoenix Meteorological Lidar instruments use external cavity doublers to generate 532-nm radiation along with the fundamental 1064-nm beam. The 532-nm beam profiles the atmospheric aerosols, while the 1064-nm beam is used for denser aerosol plumes, clouds or ground targets. ICESat lidar uses its 1064-nm beam to measure the height of the polar ice sheets and monitor its changes over time. Changes in ice sheet elevations are an important indicator of the global climate change and influence the global sea level, which can have profound impact on life on Earth. CALIPSO uses both laser wavelengths for collecting spatially resolved clouds and aerosols data. The combination of the signal returns at 1064-nm and two orthogonal polarizations of 532-nm radiation allows the scientists to extract information about cloud water and ice content, and aerosol concentration and its sources. The improved information on global coverage of clouds, their altitudes, and their water and ice contents is critical to better weather forecasting and more accurate climate models. The atmospheric aerosols also affect weather and global climate changes. Aerosols can both reflect the sunlight away from Earth, causing the atmosphere to cool and absorb the sunlight, warming the atmosphere depending on aerosol concentration and composition. Figure 1 illustrates the CALIPSO instrument and its measurements of atmospheric aerosols and clouds. CALIPSO payload also include an Imaging Infrared Radiometer (IIR) and a Wide Field Camera (WFC) to provide additional data for determining the cloud emissivity and ice particle size distribution.

Unlike ICESat and CALIPSO, the Mars Meteorological Lidar onboard Phoenix operates from a stationary platform on the ground looking upward. The Mars Meteorological Lidar measures the atmospheric aerosol concentration and $\mathrm{CO}_{2}$ ice clouds that can lead to a better understanding of Mars climate and atmospheric processes. The laser altimeter instruments (MLA and LOLA) orbiting Mercury and the moon simply measure the distance to the surface as they orbit. The data collected after a large number of orbits enable the development of global threedimensional topographical maps.

Table 1. Current NASA Space-based Scientific Lidar Instruments.

\begin{tabular}{|l||c|c||c|c|c|c|c||c|c|c|}
\hline Mission & $\begin{array}{c}\text { Lidar } \\
\text { Instruments }\end{array}$ & $\begin{array}{c}\text { Primary data } \\
\text { products }\end{array}$ & $\begin{array}{c}\text { Pulse } \\
\text { Energy }\end{array}$ & $\begin{array}{c}\text { Rep } \\
\text { rate }\end{array}$ & $\begin{array}{c}\text { No. of } \\
\text { Pump } \\
\text { Bars }\end{array}$ & $\begin{array}{c}\text { Peak } \\
\text { Power/bar }\end{array}$ & $\begin{array}{c}\text { No. } \\
\text { of } \\
\text { lasers }\end{array}$ & $\begin{array}{c}\text { Telescope } \\
\text { Aperture } \\
\text { Diameter }\end{array}$ & $\begin{array}{c}\text { Launch } \\
\text { date }\end{array}$ & $\begin{array}{c}\text { Required } \\
\text { Lifetime } \\
\text { In Space }\end{array}$ \\
\hline $\begin{array}{l}\text { ICESat } \\
\text { Earth Science) }\end{array}$ & $\begin{array}{c}\text { Laser } \\
\text { Altimeter w/ } \\
\text { atm channel }\end{array}$ & $\begin{array}{c}\text { Ice sheet } \\
\text { height, Clouds }\end{array}$ & $110 \mathrm{~mJ}$ & 40 & 54 & $65-85 \mathrm{~W}$ & 3 & $100 \mathrm{~cm}$ & $\begin{array}{c}\text { January } \\
12,2003\end{array}$ & 3 \\
\hline $\begin{array}{l}\text { CALIPSO } \\
\text { Earth Science) }\end{array}$ & $\begin{array}{c}\text { Atmospheric } \\
\text { Backscatter }\end{array}$ & $\begin{array}{c}\text { Clouds and } \\
\text { aerosol profiles }\end{array}$ & $220 \mathrm{~mJ}$ & 20 & 192 & $50 \mathrm{~W}$ & 2 & $100 \mathrm{~cm}$ & $\begin{array}{c}\text { April 28, } \\
2006\end{array}$ & 3 \\
\hline MESSENGER & $\begin{array}{c}\text { Laser } \\
\text { Altimeter }\end{array}$ & $\begin{array}{c}\text { Mercury } \\
\text { Surface } \\
\text { Topography }\end{array}$ & $20 \mathrm{~mJ}$ & 8 & 10 & $100 \mathrm{~W}$ & 1 & $\begin{array}{c}11.5 \mathrm{~cm} \\
\text { X4 }\end{array}$ & $\begin{array}{c}\text { August 3, } \\
2004\end{array}$ & 7 \\
\hline $\begin{array}{l}\text { Phoenix Mars } \\
\text { Lander }\end{array}$ & $\begin{array}{c}\text { Atmospheric } \\
\text { Backscatter }\end{array}$ & $\begin{array}{c}\text { Mars aerosol, } \\
\text { Ice clouds }\end{array}$ & $1 \mathrm{~mJ}$ & 100 & & & 1 & $10 \mathrm{~cm}$ & August 4, \\
2007 & 0.2 \\
\hline $\begin{array}{l}\text { Lunar } \\
\text { Reconnaissance } \\
\text { Orbiter }\end{array}$ & $\begin{array}{c}\text { Laser } \\
\text { Altimeter }\end{array}$ & $\begin{array}{c}\text { global lunar } \\
\text { topographic } \\
\text { model }\end{array}$ & $2.7 \mathrm{~mJ}$ & 28 & 4 & $70 \mathrm{~W}$ & 2 & $14 \mathrm{~cm}$ & Late 2008 & 2 \\
\hline
\end{tabular}

ICESat and CALIPSO have been in Earth orbit since 2003 and 2006, respectively, and are continuing to operate and transmit data. MESSENGER (MErcury Surface, Space ENvironment, GEochemistry, and Ranging) made its first flyby of Mercury in January 2008, 
making lidar measurements of the planet's surface. The lidar onboard MESSENGER is expected to operate well beyond 2011 when the spacecraft settles in Mercury's orbit after flybys in October 2008 and September 2009. The Mars Meteorological Lidar is expected to provide clouds, fogs, and dust plumes data leading to be better understanding of the Mars climate after the successful recent landing of Phoenix spacecraft in May 2008.

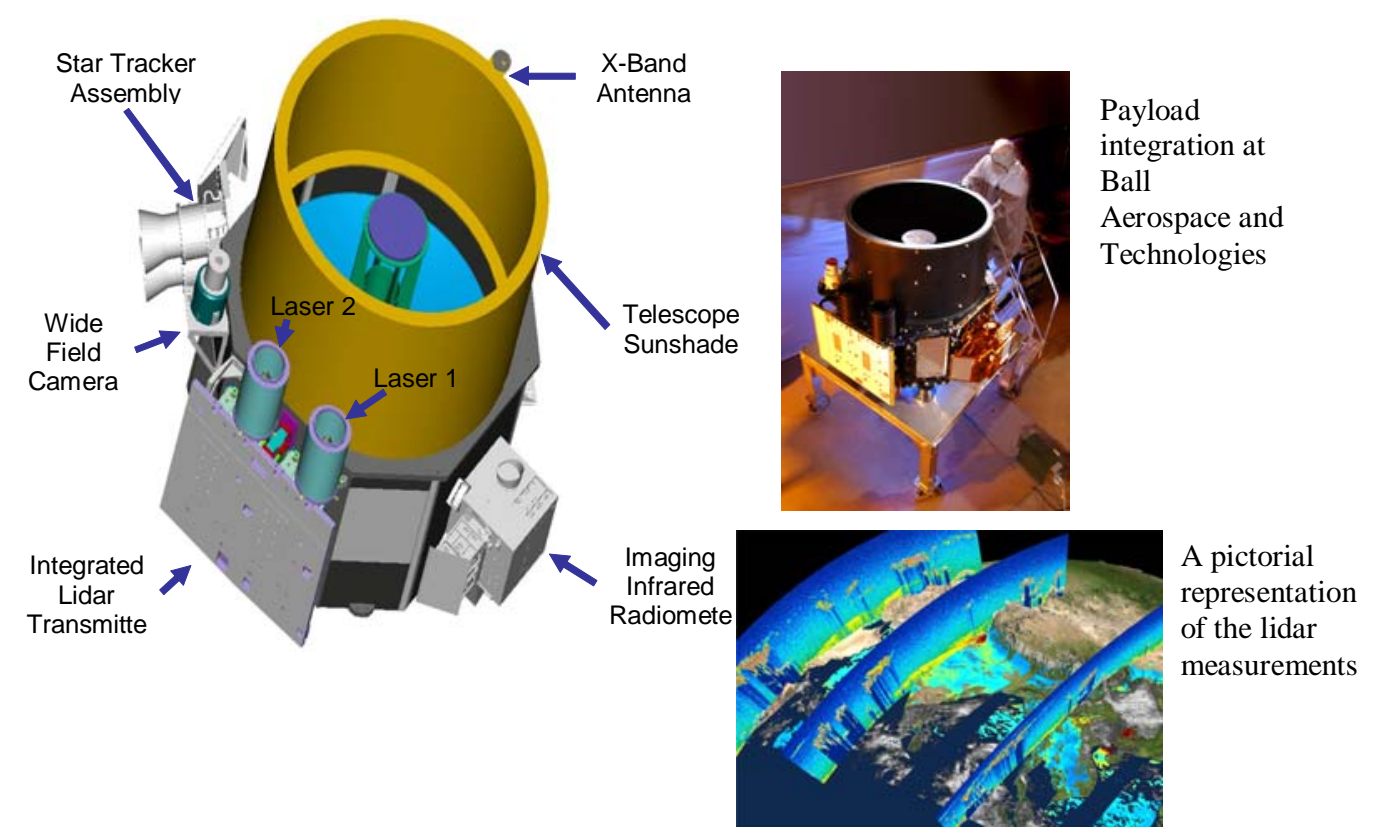

Figure 1. CLAIPSO instrument and a pictorial representation of the its measurements.

\section{CANDIDATE LIDAR INSTRUMENTS FOR FUTURE NASA MISSIONS}

The lidar technology is now planned for a wide range of applications that can enable NASA's achievement of its scientific and space exploration goals. These applications fall into four general categories:

a) Earth Science: long-duration orbiting instruments providing global monitoring of the atmosphere and land

b) Planetary Science: orbiting or land-based scientific instruments providing geological and atmospheric data of solar system bodies

c) Landing Aid: sensors providing hazard avoidance, guidance and navigation data

d) Rendezvous and Docking Aid: sensors providing spacecraft bearing, distance, and approach velocity

\section{Earth Science Applications}

Earth science reliance on lidar technology is clearly revealed in a National Research Council (NRC) report published in 2007, entitled "Earth Science and Applications from Space: 
National Imperatives for the Next Decade and Beyond” [6]. This report reflects the scientific community's consensus and is regarded very seriously by NASA planners. It provides a list of 15 recommended missions for NASA to implement over the next decade. Seven of the 15 are based on lidar instruments, with the remaining missions divided between passive optical, radar and microwave instrument technologies. This fact reflects the scientific community's belief that the ability of lidar to provide highly accurate atmospheric data on a global scale can profoundly help climate research. Table 2 lists the lidar missions recommended by the NRC and provides their associated cost, estimated by the NRC panel, reflecting their relative complexity.

Some of the NRC recommended lidar mission concepts are based on previously flown instruments but strive for higher accuracy, resolution and coverage than their predecessors. ICESat-II and ACE are two such missions that will be built upon the experiences and successes of ICESat and CALIPSO missions. However, most of the NRC recommended lidar missions represent new measurements requiring considerably more complex instruments than previously flown. For instance, the three-dimensional Wind Lidar will use highly spectral pure pulsed lasers to allow extraction of wavelength Doppler shift resulting from atmospheric aerosols and molecules in motion with the wind. Therefore, the high-pulse energy transmitter laser has to employ an elaborate cavity control mechanism and then use a separate stable, single frequency, continuous-wave laser as a injection-seeding source. Furthermore, a wind lidar requires precision pointing of the transmitted laser beam in several different directions to allow for extraction of the horizontal components of vector wind velocity. Precision scanning of the laser beam and collecting the returned radiation using an aperture of greater than $50 \mathrm{~cm}$ will be a major challenge $[7,8]$.

Table 2. Earth Science Missions Recommended by National Research Council

\begin{tabular}{|c|c|c|c|}
\hline Mission & Mission Description & Timeframe & Instrument \\
\hline ICESat-II & Ice sheet height changes for climate change diagnosis & \multirow{2}{*}{$\begin{array}{l}2010 \\
\text { to } \\
2013\end{array}$} & Laser altimeter \\
\hline DESDynI & $\begin{array}{l}\text { Surface and ice sheet deformation for understanding } \\
\text { natural hazards and climate; vegetation structure for } \\
\text { ecosystem health }\end{array}$ & & Laser altimeter \\
\hline ASCENDS & $\begin{array}{l}\text { Day/night, all-latitude, all-season } \quad \mathrm{CO}_{2} \text { column } \\
\text { integrals for climate emissions }\end{array}$ & \multirow{2}{*}{$\begin{array}{l}2013 \\
\text { to } \\
2016\end{array}$} & Multifrequency laser \\
\hline ACE & $\begin{array}{l}\text { Aerosol and cloud profiles for climate and water } \\
\text { cycle; ocean color for open ocean biogeochemistry }\end{array}$ & & Backscatter lidar \\
\hline LIST & $\begin{array}{l}\text { Land surface topography for landslide hazards and } \\
\text { water runoff }\end{array}$ & \multirow{3}{*}{$\begin{array}{l}2016 \\
\text { to } \\
2020\end{array}$} & Laser altimeter \\
\hline GRACE-II & $\begin{array}{l}\text { High temporal resolution gravity fields for tracking } \\
\text { large-scale water movement }\end{array}$ & & $\begin{array}{l}\text { Microwave or } \\
\text { laser ranging system }\end{array}$ \\
\hline $\begin{array}{l}\text { 3D-Winds } \\
\text { (demo) }\end{array}$ & $\begin{array}{l}\text { Tropospheric winds for weather forecasting and } \\
\text { pollution transport }\end{array}$ & & Doppler lidar \\
\hline
\end{tabular}

\section{Planetary Science Applications}

Planetary science applications are mostly focused on the geology and surface topography of the moon, Mars, and other solar system bodies, as well as characterization of the Mars 
atmosphere. In addition to the missions discussed earlier, NASA will continue deployment of laser altimeters orbiting various solar bodies. Specifically, we are planning to launch the Lunar Orbiter Laser Altimeter (LOLA) later this year. LOLA is expected to orbit the moon for at least two years and provide a three-dimensional surface map of the entire lunar surface. This information will be critical in landing site selection and designing the future robotic and manned landing missions to moon.

The application of lidar technology for understanding the Mars atmosphere is starting to attract the attention of NASA scientists. The NASA report, "Mars Scientific Goals, Objectives, Investigations, and Priorities," prepared in 2006, outlines a series of measurements critical to understanding the Mars atmosphere and search for evidence of life. Many of these measurements - including atmospheric density variations, seasonal and diurnal cycles, aerosol concentration profiles, and detection of water vapor - are best achieved by lidar instruments.

\section{Planetary Landing Applications}

Landing aid is another important application of lidar technology in space. Future planetary exploration missions will require safe, precision soft-landing to target scientifically interesting sites near hazardous terrain features, such as escarpments, craters, slopes and rocks. Although the landing accuracy has steadily improved over time to approximately $10 \mathrm{~km}$ for Mars landing and $1 \mathrm{~km}$ for the moon, a drastically different guidance, navigation and control concept is required to meet future mission requirements. For example, future rovers will require better than 1 $\mathrm{km}$ landing accuracy for Mars and better than $30 \mathrm{~m}$ for the Moon. Laser radar or lidar technology can be key to meeting these objectives because it can provide high-resolution three-dimensional maps of the terrain, accurate ground proximity and velocity measurements, and it can determine atmospheric pressure and wind velocity in the case of Mars landing [9-11]. These lidar capabilities can enable the landers of the future to identify the preselected landing zone and hazardous terrain features within it, determine the optimum flight path, and accurately navigate using precision ground proximity and velocity data.

Currently, NASA is actively advancing the lidar technology for future lunar landing missions through its Autonomous Landing and Hazard Avoidance Technology (ALHAT) project. This program is developing three-dimensional imaging and Doppler velocity lidar technologies as part of the landing guidance, navigation and control system. The lidar sensors being developed under ALHAT will enable safe soft-landing of large robotic, cargo and crewed vehicles with a high degree of precision at the designated landing site under any lighting conditions.

\section{Rendezvous and Docking Application}

The future crew exploration vehicle, which is to replace the space shuttle and be used for a crewed mission to the moon, may rely on a lidar sensor for its rendezvous and docking maneuvers. The lidar technique is being considered for providing critical distance, approach velocity, and relative orientation of the docking port during the rendezvous and docking maneuver. The precision and frequent update rate offered by the lidar could be key for mating the vehicle with the International Space Station and, in the case of the human mission to the moon, for mating the lunar crew module with the Earth re-entry vehicle that will be awaiting it in the moon orbit. 


\section{SUMMARY}

The lidar technology will play an increasingly important role in NASA's plan. Lidar will be used for a wide range of applications both as a scientific instrument and as a GN\&C sensor in many future NASA space missions. Despite past successful lidar missions, deployment of laser systems in space remains a very challenging task. This challenge is further evidenced by the demand for increasing accuracy with higher coverage measurements and the requirement of a number of new measurements leading to considerably complex lidar instruments.

\section{REFERENCES}

1. Schutz, B. E., H. J. Zwally, C. A. Shuman, D. Hancock, and J. P. DiMarzio, “Overview of the ICESat Mission,” Geophys. Res. Lett., 32, November 2005.

2. Abshire, J. B., X. Sun, H. Riris, J. M. Sirota, J. F. McGarry, S. Palm, D. Yi, and P. Liiva, "Geoscience Laser Altimeter System (GLAS) on the ICESat Mission: On-orbit measurement performance,” Geophys. Res. Lett., 32, November 2005.

3. Winker, D. M., J. Pelon, and M. P. McCormick, "The CALIPSO mission: Spaceborne lidar for observation of aerosols and clouds,” Proc. SPIE 4893, 1-11, 2003

4. Winker, D. M., W. H. Hunt, and C. A. Hostetler, "Status and Performance of the CALIPSO lidar,” Proc. SPIE, 5575, 8-15, 2004.

5. Luis Ramos-Izquierdo, et al., "Optical system design and integration of the Mercury Laser Altimeter,” Applied Optics, Vol. 44, No. 9, 20 March 2005.

6. National Research Council, "Earth Science and Applications from Space: National Imperatives for the Next Decade and Beyond,” Committee on Earth Science and Applications from Space: A Community Assessment and Strategy for the Future, The National Academies Press, ISBN: 0-309-10387-8, 2007.

7. F. Amzajerdian and M. J. Kavaya, "Development of solid state coherent lidars for global wind measurements" 9th Conference on Coherent Laser Radar, June 23-27, 1997, Linkoping, Sweden.

8. M. J. Kavaya, J. Yu, G. J. Koch, F. Amzajerdian, U. N. Singh, and G. D. Emmitt, "Requirements and Technology Advances for Global Wind Measurement with a Coherent Lidar: A Shrinking Gap," SPIE International Symposium on Optics \& Photonics, Lidar Remote Sensing for Environmental Monitoring VIII, San Diego, CA, August 26-30, 2007.

9. R. R. Baize, F. Amzajerdian, R. Tolson, J. Davidson, R. W. Powell, and F, Peri, "Lidar Technology Role in Future Robotic and Manned Missions to Solar System Bodies," Symposium of Advanced Devices and Materials for Laser Remote Sensing, Materials Research Society Proceedings, Vol. 883, 2005.

10. A. E. Johnson, A. R. Klumpp, J. B. Collier, and A. A. Wolf, "Lidar-Based Hazard Avoidance for Safe Landing on Mars,” AIAA Journal Of Guidance, Control, and Dynamics, Vol. 25, No. 6, 2002.

11. Wong, E.C., et al.,"Autonomous Guidance and Control Design for Hazard Avoidance and Safe Landing on Mars", AIAA Atmospheric Flight Mechanics Conference and Exhibit 5-8, 4619, Monterey, California, August 2002. 